\section{Epidemiology of high blood pressure among
the Kaingang people on the Xapecó Indigenous \\ Epidemiology of high blood pressure among
the Kaingang people on the Xapecó Indigenous Land in Santa Catarina State, Brazil, 2013}

\author{
Epidemiologia da hipertensão arterial em \\ indígenas Kaingang, Terra Indígena Xapecó, \\ Santa Catarina, Brasil, 2013
}

\author{
Epidemiología de la hipertensión en los indígenas \\ Kaingang, Tierra Indígena Xapecó, Santa \\ Catarina, Brasil, 2013
}

( ARTIGO A

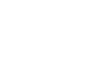

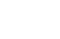




\section{Introduction}

The world population has undergone changes in its morbidity and mortality profile since the early $20^{\text {th }}$ century 1 . Known as the epidemiological transition, such changes appeared in Brazil particularly since the mid-20th century 2,3 . The currently available data have not allowed identifying an equivalent trend for Brazil's indigenous peoples as a whole. Even so, while precarious sanitation and difficult access to healthcare services contribute to the prevalence of infectious and parasitic diseases, studies have also pointed to increasingly high rates of non-communicable diseases (NCDs) among some Brazilian indigenous peoples 4,5 .

Contact and interaction between indigenous peoples and the non-indigenous population lead to economic, social, cultural, and environmental changes, especially due to encroachment on traditional indigenous lands. Such changes affect indigenous subsistence systems and lead to nutritional deficiencies and impoverishment 6,7 . The decrease in traditional hunting and fishing and the introduction of a monetary economy and paid work often result in lower levels of physical activity and increased access to Western foods, especially industrialized products 8 . The latter are associated with a monotonous diet, rich in carbohydrates and poor in protein, vitamins, and minerals, combining with other factors to cause NCDs in traditional societies in the world 8 . Contact with non-indigenous populations has thus played a significant role in the emergence and expansion of NCDs among indigenous peoples 8 .

The available data on arterial hypertension among indigenous peoples in Brazil are scarce, thus hindering a more comprehensive picture of its distribution and prevalence. However, some studies have found an increase in blood pressure levels since contact between indigenous peoples and the non-indigenous population 4,5,9. In addition, NCDs have increased more rapidly among indigenous peoples when compared to the Brazilian population as a whole 4,5,9,10,11.

In general, indigenous peoples suffer from unfavorable living conditions when compared to the non-indigenous population 12 . The rate and severity of cardiovascular diseases, including arterial hypertension, are higher among indigenous peoples 13 and thus have a greater impact on mortality 12 . Among the Kaingang people, despite a growing body of literature on their health conditions 14,15 , there is little research on hypertension. Thus, the increasing rates of NCDs among indigenous peoples in Brazil and the new demands placed on healthcare services highlight the relevance of studies on their epidemiological profile in order for the resulting data to orient healthcare planning and services. The current study aimed to describe the prevalence of high blood pressure - HBP (measured at one sitting, and suggestive of a clinical diagnosis of arterial hypertension), as well as mean systolic blood pressure (SBP), diastolic blood pressure (DBP), and their associations with socio-demographic and anthropometric variables in Kaingang adults on the Xapecó Indigenous Land in Santa Catarina State, Brazil, in 2013.

\section{Methods}

This was a cross-sectional survey in the village of Pinhalzinho on the Xapecó Indigenous Land. The fieldwork was done in May 2013.

\section{Study population}

Brazil currently has some 305 known indigenous peoples (totaling 900 thousand persons), speaking some 274 languages. They have distinct historical, political, and economic backgrounds, thus reflecting the important social diversity of the country's indigenous peoples ${ }^{16}$. The Kaingang are the fifth largest indigenous group in Brazil, with some 30 thousand members. They belong to the Jê linguistic family (Macro-Jê trunk) and have a history of approximately 250 years of contact with the non-indigenous population 17. The Kaingang live in the States of Rio Grande do Sul, Santa Catarina, Paraná, and São Paulo (Fundação Nacional de Saúde. Sistema de Informação de Atenção à Saúde Indígena: quantitativo de pessoas 2010. http://sis.funasa gov.br/transparencia_publica/siasiweb/Layout/ quantitativo_de_pessoas_2010.asp, accessed on 04/Apr/2012).

The Xapecó Indigenous Land, where the current study was conducted, is located in western Santa Catarina State, and its territory extends across the municipalities (counties) of Ipuaçu and Entre Rios 15. Most of the inhabitants of the Xapecó Indigenous Land belong to the Kaingang ethnic group, but there are also smaller numbers of Guarani. According to data from the Information System on Indigenous People's Healthcare (SIASI) for the year 2010, the Xapecó Indigenous Land had a population of four thousand, and Pinhalzinho village, the second largest, had 1,200 inhabitants (300 families in 280 households). O these, 550 were 20 years or older (Fundação Nacional de Saúde. Sistema de Informação de Atenção à Saúde Indígena: quantitativo de pessoas 2010. http://sis.funasa.gov.br/transparencia_pu 
blica/siasiweb/Layout/quantitativo_de_pes soas_2010.asp, accessed on 04/Apr/2012).

The study included individuals 20 years or older living in the village at the time of the data collection (in the case of women, only those who were not pregnant). All individuals that met the inclusion criteria were invited to participate. Members of the households that were not located after three visits were considered losses.

\section{Data collection}

Data were collected during home visits. Three interviewers were trained with a standard protocol for measuring height and waist circumference (WC), as well as specifically for measuring blood pressure. Data collection used a simplified physical examination (anthropometry and blood pressure) and questionnaires (socio-demographic variables). The anthropometric evaluation followed the protocol described by Lohman et al. 18. Body weight, height, and WC were measured. Weight was measured with a portable, platform-type electronic scale with a capacity of $200 \mathrm{~kg}$, accurate to 50g (LC200PP; Marte Científica, São Paulo, Brazil). Height was measured with a dismountable portable stadiometer, accurate to $1 \mathrm{~mm}$ (Alturexata, Belo Horizonte, Brazil). Waist circumference was measured with a flexible tape measure, accurate to 1mm (SN-4011; Sanny Medical, São Bernardo do Campo, Brazil). Diagnosis of nutritional status was calculated as body mass index (BMI), classified according to World Health Organization (WHO) guidelines, with the following cutoff points: BMI $<18.5 \mathrm{~kg} / \mathrm{m}^{2}$ : underweight; $18.5-24.9 \mathrm{~kg} / \mathrm{m}^{2}$ : normal weight; $25.0-29.9 \mathrm{~kg} / \mathrm{m}^{2}$ : overweight; and $\geq 30.0 \mathrm{~kg} / \mathrm{m}^{2}$ : obesity 19 . WC was treated statistically as a continuous variable or categorized in tertiles, since the cutoff points refer specifically to Europeans, South Asians, Chinese, and Japanese 20.

Blood pressure was measured with an automatic blood pressure monitor (Hem-631INT; Omron, Kyoto, Japan). Measurements were taken on the left wrist with the person sitting and after resting for at least 15 to 20 minutes. Two measurements were taken at a minimum interval of 10 minutes, and the mean value was used for the data analysis. In case of discrepant values between measurements, a third measurement was taken and the most divergent of the three was ruled out. Blood pressure levels were classified according to National Institutes of Health guidelines 21 , with high blood pressure classified as $\mathrm{SBP} \geq 140 \mathrm{mmHg}$, and/or DBP $\geq 90 \mathrm{mmHg}$. Since the measurements were taken at a single sitting, without following the entire WHO guidelines 22 (which recommend measurements on different days for diagnosing arterial hypertension), the values obtained at this single sitting were used to define presence or absence of high blood pressure. Participants were asked about physicianprescribed medication for arterial hypertension and were asked to show the medication they were currently taking. Participants currently on antihypertensive medication were automatically defined as having high blood pressure suggestive of a clinical diagnosis of hypertension (hereinafter referred to simply as "high blood pressure"), and their blood pressure was not measured. Data on use of antihypertensive medication were not complemented with information from the local primary care clinic, which lacked current data on HBP.

The target socio-demographic variables were: gender, age, marital status, schooling, type of floor in the house, type of walls in the house, type of roofing on the house, electricity, number of household residents, source of income, and gross and per capita monthly income, as used in the First National Survey of Indigenous People's Health and Nutrition in Brazil (INSNPI) 23, the 2010 Population Census of the Brazilian Institute of Geography and Statistics (IBGE. Censo demográfico de 2010: questionários. http://www. censo2010.ibge.gov.br/questionarios.php, accessed on $04 / \mathrm{Jul} / 2012$ ), or according to questions prepared by the study's authors.

\section{Data analysis}

The data were recorded, double-entered, and verified with EpiData 3.1 (EpiData Assoc., Odense, Denmark). An initial descriptive data analysis was performed with relative frequencies for the categorical variables, means and standard deviations for the symmetrical continuous variables, and medians and interquartile ranges for the asymmetrical continuous variables.

The outcome variable was HBP suggestive of a clinical diagnosis of arterial hypertension, categorized dichotomously (yes; no). Analyses were also conducted separately for SBP and DBP. The independent variables were: age, marital status, schooling, flooring material in the home, wall materials in the home, per capita income, BMI, and WC.

The association between the outcome variable and the independent variables was tested using logistic regression for categorical outcomes and linear regression for continuous outcomes. Variables were included and maintained in the analyses through backward stepwise selection. The analytical models were constructed for the independent variables to be included according to a given hierarchy, in blocks. The first 
block included age, schooling, marital status, flooring material in the home, wall materials in the home, and per capita income, and next BMI and WC. The latter two were not adjusted for each other since they are collinear. All the analyses were stratified by gender and the adjustments were performed for the variables in the same block and the one immediately preceding it, while the final model only maintained variables with $\mathrm{p} \leq 0.20$. Variables were considered statistically significant when they presented two-tailed $\mathrm{p}<0.05$, estimated by the Wald test for linear trend or heterogeneity, according to the type of variable analyzed. To assess the impact of losses, weighted analyses were tested, which yielded similar findings to the non-weighted results and are thus not shown here. Data on weight and/or height and WC were missing for some individuals and were thus not considered in the statistical analyses.

Data analysis was performed with Stata 11.0 (Stata Corp., College Station, USA).

\section{Ethical aspects}

The study was approved by the Committee for Research Ethics in Humans (CEPSH) at Universidade do Estado de Santa Catarina (UDESC), review n. 149.219 of November 15, 2012, and by the National Committee for Research Ethics (CONEP), case review n. 221.935 of March 18, 2013. The research team was authorized to enter the Kaingang Indigenous Land by the National Indian Foundation (FUNAI, case n. 29 AAEP/2013 of May 10, 2013). The research project complied with the provisions of Rulings n. 196/96 and 304/00 of the National Health Council (CNS) and its additions, and with FUNAI Directive n. 01/95. Agreement was obtained from the Kaingang community, and an informed consent form was obtained from each participant prior to data collection. At each household, the objectives, procedures, and expected results were explained according to the informed consent form, and participants' questions were answered. Data collection only began after obtaining informed consent.

\section{Results}

Participants included 355 Kaingang out of a total of 468 eligible for the study (75.9\% response rate). During the data collection period, 31 persons were not located in the village, 81 refused to participate, and one was excluded because he was physically unable to participate on any of the three visits. Losses were greater among men
(61.1\% of the losses), and the gender difference in losses was statistically significant ( $p<0.01$ ). Losses were more frequent in men 20 to 39 years of age $(p<0.01)$ and in women 40 to $59(p<0.01)$. Two hundred and seventy households were visited, of which data were not obtained from 55 due to refusals, ineligibility of the residents, or inability to locate them.

Women comprised the majority of participants $(56.1 \%)$. Age ranged from 20 to 95 years (median 37), with an interquartile range of 29 to 50 years. Households had an average of 3.9 residents. Most of the homes had wooden floors $(64.2 \%)$ and walls $(79.1 \%)$ and asbestos or zinc roofs $(98.6 \%)$. More than half of the households $(60 \%)$ had one or more members with yearround paid work. There was permanent electricity in $88.4 \%$ of the households. Table 1 shows the socio-demographic characteristics. Mean BMI in men was $26.8 \mathrm{~kg} / \mathrm{m}^{2}( \pm 4.7)$; in women, $29.2 \mathrm{~kg} / \mathrm{m}^{2}( \pm 5.9)$.

More than half of the men had high pressure levels and HBP, which was more prevalent in men than in women $(\mathrm{p}=0.02)$ (Table1). Of the men classified with HBP, $31.3 \%$ had already used antihypertensive medication prescribed by a physician, as compared to $46.9 \%$ of the women.

Bivariate analyses showed that men with four years of schooling or less, living in houses with packed-earth floors, and from the highest waist circumference stratum had the highest prevalence of HBP. Age and BMI were also directly associated with HBP. In the multivariate analysis, persons living in homes with tile floors and those with higher BMI and WC showed higher rates of HBP (Table 2).

Bivariate analyses for women showed a direct association between age and WC and HBP. There was an inverse association between schooling and HBP. In the multivariate analysis, only age and WC remained associated with HBP, and women 60 years or older showed 8.18 times greater odds of having HBP when compared to women 20-39 years of age (Table 3 ).

Systolic and diastolic blood pressure differed between men and women ( $\mathrm{p}<0.01)$. In men, mean SBP was $133.2 \mathrm{mmHg}( \pm 18.9)$ and mean DBP was $86.2 \mathrm{mmHg}$ ( \pm 12.5 ), as compared to $124.1 \mathrm{mmHg}( \pm 17.3)$ and $80.8 \mathrm{mmHg}( \pm 11.9)$ in women, respectively.

In the bivariate analysis, SBP was higher in obese men and those with high WC. The same variables remained associated in the multivariate analysis. As for DBP, in both the bivariate and multivariate analyses, only the anthropometric variables (BMI and WC) reached statistical significance, and there was a positive association between these two variables and HBP (Table 4). 
Socio-demographic and anthropometric characteristics and prevalence (\%) of high blood pressure in Kaingang men and women. Xapecó Indigenous Land, Santa Catarina State, Brazil, 2013.

\begin{tabular}{|c|c|c|c|}
\hline \multirow[t]{2}{*}{ Variables } & Men $(n=156)$ & Women ( $n=199)$ & Total $(\mathrm{N}=355)$ \\
\hline & $\%$ & $\%$ & $\%$ \\
\hline \multicolumn{4}{|l|}{ Age (years) } \\
\hline $20-39$ & 57.7 & 55.3 & 56.3 \\
\hline $40-59$ & 28.2 & 31.1 & 29.9 \\
\hline$\geq 60$ & 14.1 & 13.6 & 13.8 \\
\hline \multicolumn{4}{|l|}{ Marital status } \\
\hline Single/Widowed & 21.8 & 27.1 & 24.8 \\
\hline Married/Stable union & 78.2 & 72.9 & 75.2 \\
\hline \multicolumn{4}{|l|}{ Schooling (years) } \\
\hline $0-4$ & 50.0 & 55.8 & 53.2 \\
\hline $5-8$ & 35.3 & 24.6 & 29.3 \\
\hline$\geq 9$ & 14.7 & 19.6 & 17.5 \\
\hline \multicolumn{4}{|l|}{ Flooring material in the } \\
\hline \multicolumn{4}{|l|}{ home } \\
\hline Tile & 23.8 & 27.1 & 25.6 \\
\hline Cement & 7.0 & 8.6 & 7.9 \\
\hline Wood & 66.0 & 61.3 & 63.4 \\
\hline Terra & 3.2 & 3.0 & 3.1 \\
\hline \multicolumn{4}{|l|}{ Wall materials in the home } \\
\hline Brick & 22.4 & 24.6 & 23.7 \\
\hline Wood & 77.6 & 75.4 & 76.3 \\
\hline Per capita income $(\mathrm{R} \$)$ * & $301.00(200.00-500.00)$ & 300.00 (175.60-453.30) & $300.00(183.50-456.00)$ \\
\hline \multicolumn{4}{|l|}{ BMI } \\
\hline Normal & 43.8 & 24.4 & 32.9 \\
\hline Overweight & 33.3 & 34.5 & 34.0 \\
\hline Obese & 22.9 & 41.1 & 33.1 \\
\hline$W C(\mathrm{~cm}) * \star$ & $88.1( \pm 11.8)$ & $87.1( \pm 11.8)$ & $87.5( \pm 11.8)$ \\
\hline \multicolumn{4}{|l|}{$\mathrm{HBP} \star \star \star$} \\
\hline No & 46.8 & 59.3 & 53.8 \\
\hline Yes & 53.2 & 40.7 & 46.2 \\
\hline
\end{tabular}

BMI: body mass index; HBP: high blood pressure; WC: waist circumference.

* Variable shown as the median and interquartile range;

** Variable shown as the mean and standard deviation;

$\star \star \star$ Suggestive of a clinical diagnosis of arterial hypertension.

In women, high SBP was associated with age 40 to 59 years, four years of schooling or less, and high WC. In the multivariate analysis, only age reached statistical significance; the other variables were not significantly associated with SBP. Schooling and WC were positively associated with DBP in the bivariate analysis. In the multivariate analysis, only schooling remained associated (Table 5).

\section{Discussion}

The first studies on blood pressure among indigenous peoples in Brazil date to the 1950s and 1960s and showed average-to-low levels, with the absence of arterial hypertension 9,24. The first studies reporting blood pressure levels consistent with arterial hypertension were published in the late 1990s and early 2000s 25,26. Among all the studies identified, the current study shows nearly half of the adults with high blood pressure, the highest reported prevalence rate for HBP among indigenous peoples in Brazil. This result is 
Prevalence (\%) of high blood pressure and crude odds ratio (OR) and adjusted for male gender. Xapecó Indigenous Land, Santa Catarina State, Brazil, 2013.

\begin{tabular}{|c|c|c|c|c|}
\hline Variables & $\mathrm{n}$ & HBP * prevalence (\%) & $\begin{array}{l}\text { Crude analysis } \\
\text { OR }(95 \% \mathrm{Cl})\end{array}$ & $\begin{array}{c}\text { Adjusted analysis ** } \\
\text { OR }(95 \% \mathrm{Cl})\end{array}$ \\
\hline Age (years) & & & $\mathrm{p}<0.01 * \star \star$ & $p=0.113^{\star \star \star}$ \\
\hline $20-39$ & 90 & 43.3 & 1.00 & 1.00 \\
\hline $40-59$ & 44 & 61.4 & $2.07(0.99 ; 4.33)$ & $1.37(0.58 ; 3.25)$ \\
\hline$\geq 60$ & 22 & 77.3 & $4.44(1.50 ; 13.26)$ & $2.46(0.72 ; 8.45)$ \\
\hline Marital status & & & $p=0.255$ & $p=0.310$ \\
\hline Single/Widowed & 34 & 61.8 & 1.00 & 1.00 \\
\hline Married/Stable union & 122 & 50.8 & $0.63(0.29 ; 1.40)$ & $0.63(0.26 ; 1.51)$ \\
\hline Schooling (years) & & & $p=0.048$ & $p=0.170$ \\
\hline $0-4$ & 78 & 62.8 & 1.00 & 1.00 \\
\hline $5-8$ & 55 & 41.8 & $0.42(0.21 ; 0.86)$ & $0.47(0.21 ; 1.05)$ \\
\hline$\geq 9$ & 23 & 47.8 & $0.54(0.21 ; 1.40)$ & $0.51(0.16 ; 1.61)$ \\
\hline Flooring material in the home & & & $p=0.016$ & $p=0.021$ \\
\hline Tile & 37 & 72.9 & 1.00 & 1.00 \\
\hline Cement & 11 & 45.4 & $0.31(0.08 ; 1.24)$ & $0.26(0.60 ; 1.11)$ \\
\hline Wood & 103 & 45.6 & $0.31(0.14 ; 0.71)$ & $0.25(0.10 ; 0.61)$ \\
\hline Packed earth & 5 & 80.0 & $1.48(0.15 ; 14.90)$ & $0.70(0.05 ; 9.18)$ \\
\hline Wall materials in the home & & & $p=0.191$ & $p=0.405$ \\
\hline Brick & 35 & 62.8 & 1.00 & 1.00 \\
\hline Wood & 121 & 50.4 & $0.60(0.28 ; 1.30)$ & $1.75(0.43 ; 7.16)$ \\
\hline Per capita income (R\$) & & & $p=0.146$ & $\mathrm{p}=0.119 \star \star \star$ \\
\hline 1st tertile: $50.00-227.99$ & 51 & 49.0 & 1.00 & 1.00 \\
\hline 2nd tertile: $228.00-424.99$ & 50 & 46.0 & $0.88(0.40 ; 1.93)$ & $1.03(0.44 ; 2.41)$ \\
\hline 3rd tertile: $425.00-1,750.00$ & 55 & 63.6 & $1.82(0.84 ; 3.96)$ & $1.97(0.82 ; 4.72)$ \\
\hline BMI & & & $p=0.023 * \star \star$ & $p<0.01 * \star \star$ \\
\hline Normal & 67 & 46.3 & 1.00 & 1.00 \\
\hline Overweight & 51 & 49.0 & $1.12(0.54 ; 2.31)$ & $1.21(0.53 ; 2.77)$ \\
\hline Obese & 35 & 71.4 & $2.90(1.21 ; 6.97)$ & $3.47(1.59 ; 11.57)$ \\
\hline WC $(\mathrm{cm})$ & & & $p=0.023$ & $p=0.015$ \\
\hline 1st tertile: $68.0-81.9$ & 49 & 51.0 & 1.00 & 1.00 \\
\hline 2nd tertile: $82.0-90.9$ & 53 & 41.5 & $0.68(0.31 ; 1.49)$ & $0.66(0.27 ; 1.58)$ \\
\hline 3rd tertile: 91.0-151.9 & 50 & 66.0 & $2.04(0.90 ; 4.61)$ & $2.51(1.02 ; 6.19)$ \\
\hline
\end{tabular}

BMI: body mass index; WC: waist circumference; OR: odds ratio; $95 \% \mathrm{Cl}$ : $95 \%$ confidence interval.

* HBP: high blood pressure; suggestive of a clinical diagnosis of arterial hypertension;

** Adjusted for other variables from the same level or higher with $p \leq 020$. Only variables with $p \leq 0.20$ were kept in the final model:

*** p-value for linear trend.

Note: the anthropometric variables (BMI and WC) were not adjusted for each other, since they are collinear.

particularly significant considering that the sample consisted of a relatively young population (56.3\% were 39 or younger).

Housing standards in the Pinhalzinho village differed somewhat from those in the INSNPI survey 27 . In Brazil as a whole and in the South and Southeast regions, there are more homes with tile, cement, or packed-earth floors, while in the current study most of the houses had wood floors. Some $80 \%$ of the households had wooden walls, and the rest were made of brick. According to data from the INSNPI, a large share of indigenous homes in Brazil and in the South/Southeast are built of wood $(41.8 \%$ and $44.8 \%$, respectively) and brick (32.4\% and $31.9 \%$, respectively), with the rest made of mud-and-wattle or canvas and plastic 27. Most of the roofs in Pinhalzinho were made of zinc or asbestos tiles (98.6\%), with the 
Prevalence (\%) of high blood pressure and crude odds ratio (OR) and adjusted for female gender. Xapecó Indigenous Land, Santa Catarina State, Brazil, 2013.

\begin{tabular}{|c|c|c|c|c|}
\hline Variables & $n$ & HBP * prevalence (\%) & $\begin{array}{l}\text { Crude analysis } \\
\text { OR }(95 \% \mathrm{Cl})\end{array}$ & $\begin{array}{c}\text { Adjusted analysis ** } \\
\text { OR }(95 \% \mathrm{Cl})\end{array}$ \\
\hline Age (years) & & & $p<0.01$ *** & $p<0.01$ *** \\
\hline $20-39$ & 110 & 20.9 & 1.00 & 1.00 \\
\hline $40-59$ & 62 & 61.3 & $5.98(3.01 ; 11.90)$ & $4.17(2.22 ; 9.98)$ \\
\hline$\geq 60$ & 27 & 74.0 & $10.80(4.07 ; 28.67)$ & $8.18(2.90 ; 23.04)$ \\
\hline Marital status & & & $p=0.994$ & $p=0.207$ \\
\hline Single/Widowed & 54 & 40.7 & 1.00 & 1.00 \\
\hline Married/Stable union & 145 & 40.7 & $1.00(0.53 ; 1.88)$ & $1.63(0.76 ; 3.51)$ \\
\hline Schooling (years) & & & 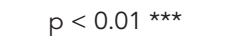 & $p=0.098^{\star \star \star \star}$ \\
\hline $0-4$ & 111 & 55.8 & 1.00 & 1.00 \\
\hline $5-8$ & 49 & 24.6 & $0.31(0.15 ; 0.64)$ & $0.60(0.26 ; 1.39)$ \\
\hline$\geq 9$ & 39 & 19.6 & $0.21(0.09 ; 0.52)$ & $0.54(0.20 ; 1.44)$ \\
\hline Flooring material in the home & & & $p=0.466$ & $p=0.458$ \\
\hline Tile & 54 & 33.3 & 1.00 & 1.00 \\
\hline Cement & 17 & 52.9 & $2.25(0.74 ; 6.81)$ & $1.46(0.41 ; 5.12)$ \\
\hline Wood & 122 & 41.8 & $1.44(0.73 ; 2.81)$ & $0.54(0.17 ; 1.66)$ \\
\hline Packed earth & 6 & 50.0 & $2.00(0.37 ; 10.92)$ & $0.33(0.03 ; 2.90)$ \\
\hline Wall materials in the home & & & $p=0.320$ & $p=0.572$ \\
\hline Brick & 49 & 34.7 & 1.00 & 1.00 \\
\hline Wood & 150 & 42.7 & $1.40(0.71 ; 2.74)$ & $1.23(0.58 ; 2.61)$ \\
\hline Per capita income $(\mathrm{R} \$)$ & & & $p=0.898$ & $p=0.315^{\star \star \star *}$ \\
\hline 1st tertile: $25.00-227.99$ & 75 & 41.3 & 1.00 & 1.00 \\
\hline 2nd tertile: $228.00-424.99$ & 61 & 37.7 & $0.86(0.43 ; 1.72)$ & $0.92(0.41 ; 2.03)$ \\
\hline 3rd tertile: $425.00-3,330.00$ & 61 & 41.0 & $0.98(0.50 ; 1.96)$ & $0.62(0.26 ; 1.49)$ \\
\hline BMI & & & $p=0.223$ & $p=0.265^{\star \star \star}$ \\
\hline Normal & 48 & 31.2 & 1.00 & 1.00 \\
\hline Overweight & 68 & 47.1 & $1.95(0.90 ; 4.24)$ & $1.57(0.64 ; 3.84)$ \\
\hline Obese & 81 & 42.0 & $1.59(0.75 ; 3.38)$ & $1.69(0.71 ; 4.02)$ \\
\hline$W C(\mathrm{~cm})$ & & & $p=0.018^{\star \star \star}$ & $p=0.044^{\star \star \star}$ \\
\hline 1st tertile: 63.0-81.9 & 67 & 29.8 & 1.00 & 1.00 \\
\hline $2^{\text {nd }}$ tertile: $82.0-90.9$ & 64 & 43.7 & $1.83(0.89 ; 3.75)$ & $1.65(0.71 ; 3.81)$ \\
\hline 3rd tertile: 91.0-141.9 & 64 & 50.0 & $2.35(1.15 ; 4.81)$ & $2.40(1.02 ; 5.61)$ \\
\hline
\end{tabular}

BMI: body mass index; WC: waist circumference; OR: odds ratio; $95 \% \mathrm{Cl}$ : $95 \%$ confidence interval

* HBP: high blood pressure; suggestive of a clinical diagnosis of arterial hypertension;

** Adjusted for other variables from the same level or higher with $p \leq 020$. Only variables with $p \leq 0.20$ were kept in the final model;

*** p-value for linear trend.

Note: the anthropometric variables (BMI and WC) were not adjusted for each other, since they are collinear.

rest made of ceramic tiles. In the South/Southeast, the INSNPI found mainly ceramic roof tiles 27. Living conditions are unequal between Brazilian indigenous and non-indigenous families, particularly in access to running water, basic sanitation, and solid waste management 27 . According to Kühl et al. 14 , in indigenous communities the use of non-durable building materials does not necessarily mean lower socioeconomic status and should not be interpreted immediately as such, but only after careful analysis of the local context. However, the authors highlight that in the specific context of the Kaingang from the Mangueirinha Indigenous Land in Paraná State, the materials used to build walls in the homes could in fact be used as a proxy for socioeconomic status 14 
Table 4

Mean levels of systolic blood pressure (SBP) and diastolic blood pressure (DBP): crude and adjusted analysis for male gender. Xapecó Indigenous Land, Santa Catarina State, Brazil, 2013.

\begin{tabular}{|c|c|c|c|c|c|}
\hline \multirow[t]{3}{*}{ Variables } & \multirow[t]{3}{*}{$\mathrm{n}$} & \multicolumn{2}{|c|}{ SBP $(\mathrm{mmHg})$} & \multicolumn{2}{|c|}{$\mathrm{DBP}(\mathrm{mmHg})$} \\
\hline & & Crude analysis & Adjusted analysis * & Crude analysis & Adjusted analysis * \\
\hline & & Mean (SD) & $\boldsymbol{\beta}$ & Mean (SD) & $\beta$ \\
\hline Age (years) & & $p=0.063 \star \star$ & $p=0.323 * \star$ & $p=0.140 * \star$ & $p=0.361$ \\
\hline 20-39 & 84 & $131.1( \pm 18.1)$ & 0.0 & $84.7( \pm 11.6)$ & 0.0 \\
\hline $40-59$ & 36 & $135.9( \pm 18.9)$ & 3.3 & $88.7( \pm 12.3)$ & 3.8 \\
\hline$\geq 60$ & 10 & $140.9( \pm 24.5)$ & 5.4 & $90.4( \pm 18.6)$ & 3.7 \\
\hline Marital status & & $p=0.279$ & $p=0.413$ & $p=0.732$ & $p=0.905$ \\
\hline Single/Widowed & 28 & $136.7( \pm 16.4)$ & 0.0 & $87.0( \pm 11.6)$ & 0.0 \\
\hline Married/Stable union & 102 & $132.3( \pm 19.6)$ & -3.5 & $86.1( \pm 12.8)$ & -0.3 \\
\hline Schooling (years) & & $p=0.320$ & $p=0.502$ & $p=0.723$ & $p=0.936$ \\
\hline $0-4$ & 60 & $127.8( \pm 18.9)$ & 0.0 & $87.2( \pm 14.4)$ & 0.0 \\
\hline $5-8$ & 49 & $122.1( \pm 15.0)$ & -4.6 & $85.4( \pm 11.3)$ & -0.9 \\
\hline$\geq 9$ & 21 & $118.5( \pm 14.6)$ & -3.8 & $85.5( \pm 9.3)$ & -0.6 \\
\hline Flooring material in the home & & $p=0.254$ & $p=0.411$ & $p=0.109$ & $p=0.239$ \\
\hline Tile & 28 & $138.4( \pm 19.8)$ & 0.0 & $89.6( \pm 11.9)$ & 0.0 \\
\hline Cement & 10 & $128.5( \pm 12.5)$ & -9.9 & $84.9( \pm 10.2)$ & -4.9 \\
\hline Wood & 90 & $131.9( \pm 18.8)$ & -7.3 & $85.1( \pm 12.3)$ & -4.4 \\
\hline Packed earth & 2 & $146.2( \pm 38.5)$ & 3.2 & $102.0( \pm 33.2)$ & 11.3 \\
\hline Wall materials in the home & & $p=0.616$ & $p=0.883$ & $p=0.385$ & $p=0.905$ \\
\hline Brick & 26 & $134.9( \pm 18.7)$ & 0.0 & $88.2( \pm 12.4)$ & 0.0 \\
\hline Wood & 104 & $132.8( \pm 19.1)$ & 0.9 & $85.8( \pm 12.6)$ & 0.5 \\
\hline Per capita income (R\$) & & $p=0.361$ & $p=0.506$ & $p=0.584$ & $p=0.755$ \\
\hline 1st tertile: $50.00-227.99$ & 44 & $135.6( \pm 22.6)$ & 0.0 & $87.2( \pm 13.8)$ & 0.0 \\
\hline 2nd tertile: $228.00-424.99$ & 47 & $130.1( \pm 16.1)$ & -4.6 & $84.8( \pm 10.9)$ & -1.7 \\
\hline 3rd tertile: $425.00-1,750.00$ & 39 & $134.2( \pm 17.7)$ & -1.4 & $87.0( \pm 13.0)$ & 0.0 \\
\hline BMI & & $p=0.046$ ** & $p=0.046$ ** & $p=0.027 \star \star$ & $p=0.027 \star \star$ \\
\hline Normal & 54 & $129.2( \pm 18.2)$ & 0.0 & $83.5( \pm 10.3)$ & 0.0 \\
\hline Overweight & 46 & $135.5( \pm 21.4)$ & 6.3 & $87.8( \pm 14.6)$ & 4.2 \\
\hline Obese & 28 & $137.3( \pm 15.5)$ & 8.1 & $89.5( \pm 11.9)$ & 6.0 \\
\hline WC (cm) & & $\mathrm{p}<0.01 \star \star$ & $\mathrm{p}<0.01 \star \star$ & $\mathrm{p}<0.01 \star \star$ & $\mathrm{p}<0.01 * \star$ \\
\hline 1st tertile: $68.0-81.9$ & 39 & $127.8( \pm 13.6)$ & 0.0 & $82.9( \pm 9.1)$ & 0.0 \\
\hline 2nd tertile: $82.0-90.9$ & 47 & $131.4( \pm 19.8)$ & 3.6 & $84.7( \pm 11.9)$ & 1.9 \\
\hline 3rd tertile: 91.0-151.9 & 41 & $140.7( \pm 20.9)$ & 13.0 & $91.5( \pm 14.5)$ & 8.7 \\
\hline
\end{tabular}

BMI: body mass index; SD: standard deviation; WC: waist circumference.

* Adjusted for other variables from the same level or higher with $p \leq 020$. Only variables with $p \leq 0.20$ were kept in the final model;

** $\mathrm{p}$-value for linear trend.

Note: the anthropometric variables (BMI and WC) were not adjusted for each other, since they are collinear.

The relative scarcity of studies on hypertension among indigenous peoples in Brazil may further hinder the comparison of results between studies, due to the use of different cutoff points to define high blood pressure. Two recent case studies were done among the Kaingang on the Faxinal Indigenous Land in central Paraná State and in the village of Jaguapirú in Mato Grosso do Sul State, with Teréna, Kaiowá, and Guarani adults. Both aimed to verify the prevalence of meta- bolic syndrome, using SBP 130mmHg and DBP 85mmHg to identify HBP (suggestive of a clinical diagnosis of arterial hypertension). These cutoff points were different than the ones we used here 28,29 . The first study included 82 adults and showed a $24.2 \%$ HBP rate in men and $28.6 \%$ in women ${ }^{29}$. The second study included 606 adults and found HBP in $46.3 \%$ of the men and $37.5 \%$ of the women 29 . 
Mean levels of systolic blood pressure (SBP) and diastolic blood pressure (DBP): crude and adjusted analysis for female gender. Xapecó Indigenous Land, Santa Catarina State, Brazil, 2013.

\begin{tabular}{|c|c|c|c|c|c|}
\hline \multirow[t]{3}{*}{ Variables } & \multirow[t]{3}{*}{$\mathrm{n}$} & \multicolumn{2}{|c|}{$\mathrm{SBP}(\mathrm{mmHg})$} & \multicolumn{2}{|c|}{$\mathrm{DBP}(\mathrm{mmHg})$} \\
\hline & & Crude analysis & Adjusted analysis * & Crude analysis & Adjusted analysis * \\
\hline & & Mean & $\boldsymbol{\beta}$ & Mean & $\beta$ \\
\hline Age (years) & & $p<0.01$ & $p=0.021$ & $p=0.084$ & $p=0.345$ \\
\hline $20-39$ & 106 & $120.5( \pm 14.4)$ & 0.0 & $79.3( \pm 11.2)$ & 0.0 \\
\hline $40-59$ & 44 & $131.2( \pm 20.9)$ & 9.2 & $83.9( \pm 13.5)$ & 3.4 \\
\hline$\geq 60$ & 11 & $129.9( \pm 18.3)$ & 5.9 & $82.6( \pm 11.4)$ & 2.1 \\
\hline Marital status & & $p=0.426$ & $p=0.218$ & $p=0.581$ & $p=0.391$ \\
\hline Single/Widowed & 42 & $122.2( \pm 18.0)$ & 0.0 & $79.9( \pm 13.4)$ & 0.0 \\
\hline Married/Stable union & 119 & $124.7( \pm 17.1)$ & 4.0 & $86.1( \pm 11.5)$ & 1.8 \\
\hline Schooling (years) & & $p<0.01 * \star$ & $p=0.205 * \star$ & $p=0.010 * *$ & $p=0.023 * \star$ \\
\hline $0-4$ & 80 & $127.8( \pm 18.9)$ & 0.0 & $82.7( \pm 12.2)$ & 0.0 \\
\hline $5-8$ & 44 & $122.1( \pm 15.0)$ & -2.2 & $81.3( \pm 10.7)$ & -2.0 \\
\hline$\geq 9$ & 37 & $118.5( \pm 14.6)$ & -4.9 & $76.3( \pm 12.0)$ & -5.6 \\
\hline Flooring material in the home & & $p=0.815$ & $p=0.948$ & $p=0.969$ & $p=0.074$ ** \\
\hline Tile & 48 & $122.6( \pm 15.7)$ & 0.0 & $81.3( \pm 10.9)$ & 0.0 \\
\hline Cement & 13 & $122.7( \pm 17.6)$ & -2.5 & $81.6( \pm 13.1)$ & -1.0 \\
\hline Wood & 96 & $124.8( \pm 18.3)$ & -2.3 & $80.4( \pm 12.6)$ & -5.3 \\
\hline Packed earth & 4 & $129.4( \pm 13.5)$ & -1.23 & $80.4( \pm 6.7)$ & -7.6 \\
\hline Wall materials in the home & & $p=0.411$ & $p=0.368$ & $p=0.618$ & $p=0.131$ \\
\hline Brick & 41 & $122.1( \pm 14.1)$ & 0.0 & $80.0( \pm 10.6)$ & 0.0 \\
\hline Wood & 120 & $124.7( \pm 18.3)$ & 4.3 & $81.1( \pm 12.4)$ & 4.8 \\
\hline Per capita income $(\mathrm{R} \$)$ & & $p=0.316$ & $p=0.347$ & $p=0.058 * \star$ & $p=0.175$ \\
\hline 1st tertile: $25.00-227.99$ & 64 & $125.1( \pm 17.7)$ & 0.0 & $83.1( \pm 12.5)$ & 0.0 \\
\hline 2nd tertile: $228.00-424.99$ & 52 & $121.0( \pm 19.1)$ & -2.9 & $79.2( \pm 12.6)$ & -3.8 \\
\hline 3rd tertile: $425.00-3,330.00$ & 44 & $125.8( \pm 14.3)$ & 2.3 & $78.9( \pm 9.7)$ & -3.3 \\
\hline BMI & & $p=0.284 * \star$ & $p=0.479$ & $p=0.114 * \star$ & $p=0.235 * \star$ \\
\hline Normal & 42 & $122.2( \pm 18.3)$ & 0.0 & $78.2( \pm 11.9)$ & 0.0 \\
\hline Overweight & 53 & $123.6( \pm 17.5)$ & -0.5 & $81.4( \pm 12.2)$ & 2.6 \\
\hline Obese & 64 & $125.8( \pm 16.8)$ & 3.0 & $82.1( \pm 11.9)$ & 3.0 \\
\hline WC (cm) & & $p=0.041 * \star$ & $p=0.090 * *$ & $p=0.023$ ** & $p=0.155^{\star *}$ \\
\hline 1st tertile: 63.0-81.9 & 59 & $121.3( \pm 18.1)$ & 0.0 & $78.1( \pm 12.7)$ & 0.0 \\
\hline 2nd tertile: $82.0-90.9$ & 51 & $123.2( \pm 17.2)$ & 0.2 & $81.6( \pm 11.0)$ & 2.3 \\
\hline 3rd tertile: 91.0-141.9 & 48 & $128.3( \pm 16.4)$ & 4.7 & $83.3( \pm 12.0)$ & 3.3 \\
\hline
\end{tabular}

BMI: body mass index; SD: standard deviation; WC: waist circumference.

* Adjusted for other variables from the same level or higher with $p \leq 020$. Only variables with $p \leq 0.20$ were kept in the final model;

** $p$-value for linear trend.

Note: the anthropometric variables (BMI and WC) were not adjusted for each other, since they are collinear.

Other studies have focused on the prevalence of HBP in adult indigenous peoples using the same diagnostic criteria as ours and found lower prevalence rates and lower mean SBP and DBP $5,26,30,31,32$. Among the Parkatêjê in Pará State, the prevalence rates for high blood pressure were $3.6 \%$ in men and $5.9 \%$ in women ${ }^{29}$. A study by Gimeno et al. 31 among the Mehináku, Waurá, and Yawalapití in the Upper Xingu found prevalence rates of $10.8 \%$ in men and $6 \%$ in women. Among the Suruí, in Rondônia State, prevalence was $2.4 \%$ in men and $3.1 \%$ in women 5 . Meyerfreund et al. 32 recorded an overall prevalence of $20.8 \%$ in the Tupinikim in Espírito Santo State. Data from the INSNPI showed HBP in $17.4 \%$ among women 14 to 49 years of age in the South/Southeast of Brazil, as compared to the national prevalence of $13.2 \% 27$. 
In this study, the prevalence of high blood pressure suggestive of hypertension exceeded that of the Brazilian population as a whole. Prevalence of a prior medical diagnosis of arterial hypertension among Brazilian adults in 2012 was approximately $24 \%$, according to the Telephone Survey for Surveillance of Risk and Protective Factors for Chronic Diseases (VIGITEL) 33. Equally high prevalence rates are found in native populations elsewhere in the world, as are differences with the non-indigenous populations in the countries where they live $34,35,36,37,38,39$. In broader terms, this reflects important differences between health indicators for indigenous and non-indigenous peoples, with indigenous peoples at a systematic disadvantage.

Only two ethnic groups in Brazil, the Xavánte and the Suruí, were studied at different moments, thereby allowing comparisons over time. Both cases showed an upward trend in blood pressure over the years, as well as the emergence of arterial hypertension. The Xavánte of the Pimentel Barbosa Indigenous Land in Mato Grosso State were examined three times over the course of more than four decades, in 1962 9, 1990 26, and 200940. The comparisons showed a major increase in mean SBP and DBP from 1962 to 2009. In addition, the first study found no cases of hypertension, while by 2009 the prevalence had reached $8.1 \%$ in men and $5.8 \%$ in women. From 1990 to 2009, there was little difference in mean SBP and DBP or prevalence of HBP (in 1990, 5.3\% in men and $7.7 \%$ in women).

Although covering a shorter time period, an equally important set of studies evaluated blood pressure among the Suruí on the Sete de Setembro Indigenous Land in Rondônia State. A study in 198841 failed to identify levels consistent with hypertension. However, 17 years later the prevalence of HBP was $2.4 \%$ in men and $3.1 \%$ in women, with an increase in mean SBP and DBP 5.

In the current study, two-thirds of the men and more than half of the women with HBP were not taking medication for hypertension. A similar proportion was found in women 18 to 49 years of age in the INSNPI survey ${ }^{23}$. This shows that among Kaingang adults and indigenous women in Brazil as a whole, more than half with high blood pressure remain untreated.

Precarious socioeconomic conditions in the majority of Brazil's indigenous peoples, especially the inequality compared to other population groups, affect their health profiles in various ways 42 and can contribute to cardiovascular diseases 34,43 . Socioeconomic disadvantage has been associated with an increase in the burden of some cardiovascular risk factors among indigenous peoples 36,44 . According to Coimbra Jr. \&
Santos 45 (p. 131), “[...] ethnic and racial minorities in Brazil experience situations of exclusion, marginalization, and discrimination which ultimately put them in a position of greater vulnerability for a number of diseases."

Brave Heart 44 points to a connection between cardiovascular diseases and other disorders such as post-traumatic stress syndrome, due to the long history of domination and oppression suffered by indigenous peoples. In addition, the fetal programming theory 46 helps explain the major role of NCDs in the epidemiological profile of these peoples, in addition to child malnutrition and vitamin deficiency diseases 23 . The theory associates prenatal nutritional deprivation with the emergence of NCDs in adulthood, including cardiovascular diseases 46 . Fetal programming can thus be an additional source of environmental risk that interacts with other factors throughout life 47 .

High prevalence rates of excess weight have also been found in indigenous peoples in Brazil $5,11,27,28,31$. The highest HBP and the highest mean SBP and DBP were in overweight or obese individuals, although this difference was only statistically significant in men. Tavares et al. ${ }^{5}$ studied the Suruí in Rondônia State and did not find a statistical association between BMI and SBP and DBP, although they did record higher mean SBP and DBP in individuals with excess weight. The same pattern was found among the Xavánte 40 in Pimentel Barbosa, Mato Grosso State, and in the Patakatêjê 30 of the Mãe Maria Indigenous Land in Pará State. According to the literature, individuals with excess weight show increased risk of developing cardiovascular diseases 21 .

WC in the current study was similar to that found in Mehináku, Waurá, and Yawalapití men and women in the Upper Xingu 31. Tavares et al. 5 found a direct association between SBP and DBP and WC among the Suruí. The current study only found a direct association between SBP and DBP and WC in men. Although not all the associations were significant, the highest prevalence rates for HBP and the highest mean SBP and DBP were found in the highest WC strata.

This study points to an association between age and HBP and mean SBP among Kaingang women. Studies have shown an increase in cases suggestive of hypertension with age 5,40,48. As with mean SBP and DBP, the dynamics can differ somewhat between studies 5,40,48. However, the positive association between hypertension and age is widely documented in the literature 22 . Men up to 60 years of age generally show the highest rates of HBP, and after 60 the rate is higher in women 21. Among the Mehináku, Waurá, 
and Yawalapití 31 prevalence of HBP was higher in men. Among the Xavánte 40, there was no difference in this variable between men and women; among the Suruí, prevalence was higher in women 5 .

Among the Kaingang, men that lived in houses with tile floors (which in this group's context reflects better socioeconomic status) showed a higher prevalence of HBP. Women with nine years of schooling or more showed higher mean DBP. A study of the Suruí in Rondônia State found more cases of high blood pressure in individuals with lower socioeconomic status, but the difference was not significant 5 . Among the Xavánte, a study found that persons with higher socioeconomic status tended to show higher mean BP and more cases suggestive of hypertension 40 .

Although some studies show higher prevalence rates for hypertension in lower socioeconomic strata, this relationship has not been fully established, since other studies point in the opposite direction, thus requiring further research. Minor et al. 49 , in a review on arterial hypertension and socioeconomic status, state that the relationship between socioeconomic determinants and blood pressure is complex and varies widely between populations, sometimes with contradictory findings.

Importantly, the Kaingang sample does not represent the entire indigenous population of
Brazil. The study was done in the South, the region with the greatest interaction between indigenous peoples and national society and a history of nearly 250 years of contact with the non-indigenous population. This is expressed through changes in the traditional indigenous lifestyle and may explain the high prevalence of HBP in the Kaingang in Pinhalzinho villange (in addition to other variables such as the sources of family income). Losses to the study sample are another possible limitation, assuming that they were non-random. However, even if all the refusals or non-responders $(n=168)$ did not have high blood pressure, the prevalence of HBP would still be $35 \%$, representing a major health problem for this group. In addition, the study did not cover other risk factors for hypertension such as diabetes, alcohol abuse, sedentary lifestyle, smoking, or diet, which could also influence the results of adjusted analyses.

More research is needed on non-communicable diseases among indigenous peoples in Brazil in order to further the understanding of specificities in the epidemiological and nutritional transition in different indigenous peoples. We hope that the data produced here will help plan health measures targeted to treatment and prevention of risk factors for hypertension, given the implications for morbidity and mortality rates from cardiovascular diseases.

\section{Resumen}

Estudio transversal, con el objetivo de describir la prevalencia de niveles tensionales sugestivos de la hipertensión arterial sistémica (NTSHAS), los niveles de presión arterial sistólica (PAS) y diastólica (PAD), y su asociación con datos sociodemográficos y antropométricos, entre 355 adultos (20+años) Kaingang (Tierra Indígena Xapecó). Se midieron peso, talla, circunferencia de cintura (CC), PAS y PAD, y se recogieron datos sociodemográficos. La prevalencia de HAS fue 53,2\% (IC95\%: 45,3; 61,1) entre los hombres y 40,7\% (IC95\%: 33,8; 47,6) en las mujeres. En ellas, la edad y la CC se asociaron positivamente a NTSHAS; la edad se asoció con la PAS y la escolaridad con la PAD. En hombres de mayor índice de masa corporal (IMC) y CC, y con casa de pisos de cerámica, se registraron mayor prevalencia de HAS; la mayor CC y mayor IMC se asociaron con mayor PAS; y el IMC y CC, directamente asociados con la PAD. Destaca la necesidad de adoptar medidas dirigidas a controlar los factores de riesgo para la NTSHAS, en vista de la alta prevalencia entre los Kaingang y su contribución en la morbilidad y la mortalidad por enfermedad cardiovascular.

Hipertensión; Indios Sudamericanos; Salud de Poblaciones Indígenas 


\section{Contributors}

D. Bresan participated in the study design, data collection, processing, and analysis, and writing of the manuscript. J. L. Bastos collaborated in the critical revision of the manuscript. M. S. Leite contributed to the study design, data processing and analysis, and writing of the manuscript.

\section{Acknowledgments}

The authors wish to thank the Kaingang people of the village of Pinhalzinho for their hospitality and willingness to participate in the study, as well as the FAPESC agency for the research funding.

\section{References}

1. Omram AR. The epidemiologic transition: a theory of the epidemiology of population change. Milbank Q 1971; 49:509-38.

2. Prata PR. A transição epidemiológica no Brasil. Cad Saúde Pública 1992; 8:168-75.

3. Batista Filho M, Rissin A. A transição nutricional no Brasil: tendências regionais e temporais. Cad Saúde Pública 2003; 19 Suppl 1:S181-91.

4. Welch JR, Ferreira AA, Santos RV, Gugelmin SA, Werneck G, Coimbra Jr. CEA. Nutrition transition, socioeconomic differentiation, and gender among adult Xavante Indians, Brazilian Amazon. Hum Ecol 2009; 37:13-26.

5. Tavares FG, Coimbra Jr. CEA, Cardoso AM. Níveis tensionais de adultos indígenas Suruí, Rondônia, Brasil. Ciênc Saúde Coletiva 2013; 18:1399-409.

6. Santos RV, Coimbra Jr. CEA. Cenários e tendências da saúde e da epidemiologia dos povos indígenas do Brasil. In: Coimbra Jr. CEA, Santos RV, Escobar $\mathrm{AL}$, organizadores. Epidemiologia e saúde dos povos indígenas no Brasil. Rio de Janeiro: Editora Fiocruz/ABRASCO; 2003. p. 13-47.
7. Leite MS, Santos RV, Coimbra Jr. CEA, Gugelmin SA. Alimentação e nutrição dos povos indígenas no Brasil. In: Kac G, Sichieri R, Gigante DP, organizadores. Epidemiologia nutricional. Rio de Janeiro: Editora Fiocruz/Editora Atheneu; 2007. p. 50317.

8. Wirsing RL. The health of traditional societies and the effects of acculturation. Curr Anthropol 1985; 26:303-22.

9. Neel JV, Salzano FM, Junqueira PC, Ketter F, Maybury-Lewis D. Studies on the Xavante Indians of the Brazilian Mato Grosso. Am J Hum Genet 1964; 16:52-140.

10. Bloch KV, Coutinho ESF, Lôbo MSC, Oliveira JEP, Milech A. Pressão arterial, glicemia capilar e medidas antropométricas em uma população Yanomámi. Cad Saúde Pública 1993; 9:428-38.

11. Leite MS, Santos RV, Gugelmin SA, Coimbra Jr. CEA. Crescimento físico e perfil nutricional da população indígena Xavánte de Sangradouro-Volta Grande, Mato Grosso, Brasil. Cad Saúde Pública 2006; 22:265-76. 
12. Gracey M, King M. Indigenous health part 1: determinants and disease patterns. Lancet 2009; 374:65-75.

13. Moe GW, Tu J. Heart failure in the ethnic minorities. Curr Opin Cardiol 2010; 25:124-30.

14. Kühl AM, Corso ACT, Leite MS, Bastos JL. Perfil nutricional e fatores associados à ocorrência de desnutrição entre crianças indígenas Kaingang da Terra Indígena de Mangueirinha, Paraná, Brasil. Cad Saúde Pública 2009; 25:409-20.

15. Diehl EE. Agravos na saúde Kaingang (Terra Indígena Xapecó, Santa Catarina) e a estrutura dos serviços de atenção biomédica. Cad Saúde Pública 2001; 17:439-45.

16. Instituto Brasileiro de Geografia e Estatística. Censo demográfico 2010: características gerais dos indígenas. Rio de Janeiro: Instituto Brasileiro de Geografia e Estatística; 2012.

17. Mota LT. As guerras dos índios Kaingang: a história épica dos índios Kaingang no Paraná (1769-1924). Maringá: EDUEM; 1994.

18. Lohman TG, Roche AF, Martorell R. Anthropometric standardization reference manual. Champaign: Human Kinetics; 1988.

19. World Health Organization. Obesity: preventing and managing the global epidemic. Geneva: World Health Organization; 1997.

20. International Diabetes Federation. The IDF consensus worldwide definition of the metabolic syndrome. Brussels: International Diabetes Federation; 2006.

21. Joint National Committee. The Seventh Report of the Joint National Committee on detection, evaluation, and treatment of high blood pressure. Washington DC: US Department of Health and Human Services; 2004.

22. World Health Organization. Hypertension control: report of a WHO Expert Committee. Geneva: World Health Organization; 1996. (WHO Technical Report Series, 862).

23. Associação Brasileira de Pós-Graduação em Saúde Coletiva. Inquérito Nacional de Saúde e Nutrição dos Povos Indígenas: relatório final. Rio de Janeiro: ABRASCO; 2010.

24. Lima PE. Níveis tensionais dos índios Kalapalo e Kamaiurá. RBM Rev Bras Med 1950; 7:787-8.

25. Cardoso AM, Mattos IE, Koifman RJ. Prevalência de fatores de risco para doenças cardiovasculares na população Guarani-Mbyá do Estado do Rio de Janeiro. Cad Saúde Pública 2001; 17:345-54.

26. Coimbra Jr. CEA, Chor D, Santos RV, Salzano FM. Blood pressure levels in Xavánte adults from the Pimentel Barbosa Indian Reservation, Mato Grosso, Brazil. Ethn Dis 2001; 11:232-40.

27. Coimbra Jr. CEA, Santos RV, Welch JR, Cardoso AM, Souza MC, Garnelo L, et al. The First National Survey of Indigenous People's Health and Nutrition in Brazil: rationale, methodology, and overview of results. BMC Public Health 2013; 13:52.

28. Anjos HNK, Toledo MJO, Mota LT, Previdelli ITS, Anjos AF, Saruhashi TR, et al. Prevalence of metabolic syndrome among Kaingang native Americans in Southern Brazil. Braz Arch Biol Technol $2011 ; 54: 81-9$.
29. Oliveira GF, Oliveira TRR, Rodrigues FF, Corrêa LF, Arruda TB, Casulari LA. Prevalence of metabolic syndrome in the indigenous population, aged 19 to 69 years, from Jaguaripu Village, Dourados (MS), Brazil. Ethn Dis 2011; 21:301-6.

30. Tavares EF, Vieira-Filho JPB, Andriolo A, Sanudo A. Metabolic profile and cardiovascular risk patterns in an indigenous population of Amazonia. Hum Biol 2003; 75:31-46.

31. Gimeno SGA, Rodrigues D, Pagliaro H, Cano EM, Lima ES, Baruzzi RG. Perfil metabólico e antropométrico de índios Aruák: Mehináku, Waurá e Yawalapití, Alto Xingu, Brasil Central, 2000/2002. Cad Saúde Pública 2007; 23:1946-54.

32. Meyerfreund D, Gonçalves CP, Cunha RS, Pereira AC, Krieger JE, Mill JG. Age-dependent increase in blood pressure in two different Native American communities in Brazil. J Hypertens 2009; 27: 1753-60.

33. Departamento de Análise de Situação de Saúde, Secretaria de Vigilância em Saúde, Ministério da Saúde. VIGITEL 2012: Vigilância de Fatores de Risco e Proteção para Doenças Crônicas por Inquérito Telefônico. Brasília: Ministério da Saúde; 2013.

34. Anand SS, Yusuf S, Jacobs R, Davis AD, Yi O, Gerstein $\mathrm{H}$, et al. Risk factors, atherosclerosis, and cardiovascular disease among Aboriginal people in Canada: the Study of Health Assessment and Risk Evaluation in Aboriginal Peoples (SHARE-AP). Lancet 2001; 358:1147-53.

35. Hoy WE, Kondalsamy-Chennakesavan S, Wang Z, Briganti E, Shaw J, Polkinghorne K, et al. Quantifying the excess risk for proteinuria, hypertension and diabetes in Australian Aborigines: comparison of profiles in three remote communities in the Northern Territory with those in the AusDiab study. Aust N Z J Public Health 2007; 31:177-83.

36. Schumacher C, Ferucci ED, Lanier AP, Slattery ML, Schraer CD, Raymer TW, et al. Metabolic syndrome: prevalence among American Indian and Alaska native people living in the Southwestern United States and in Alaska. Metab Syndr Relat Disord 2008; 6:267-73.

37. Cunningham J. Socioeconomic disparities in selfreported cardiovascular disease for Indigenous and non-Indigenous Australian adults: analysis of national survey data. Popul Health Metr 2010; 8:31.

38. Bruce SG, Riediger ND, Zacharias JM, Young TK. Obesity and obesity-related comorbidities in a Canadian First Nation Population. Chronic Dis Can 2010; 8:27-32.

39. Cameron VA, Faatoese AF, Gillies MW, Robertson PJ, Huria TM, Doughty RN, et al. A cohort study comparing cardiovascular risk factors in rural Māori, urban Māori and non-Māori communities in New Zealand. BMJ Open 2012; 2:e000799.

40. Oliveira MVG. Níveis tensionais e prevalência de hipertensão entre os Xavante, Terra Indígena Pimentel Barbosa, Mato Grosso [Masters Thesis]. Rio de Janeiro: Escola Nacional de Saúde Pública Sergio Arouca, Fundação Oswaldo Cruz; 2011. 
41. Fleming-Moran M, Santos RV, Coimbra Jr. CEA. Blood pressure levels of the Suruí and Zoró Indians of the Brazilian Amazon: group- and sex-specific effects resulting from body composition, health status, and age. Hum Biol 1991; 63:835-61.

42. Santos RV, Coimbra Jr. CEA. Saúde indígena. In: Comissão Nacional sobre Determinantes Sociais da Saúde, organizador. As causas sociais das iniquidades em saúde no Brasil. Relatório final da Comissão Nacional sobre Determinantes Sociais da Saúde. Rio de Janeiro: Editora Fiocruz; 2008. p. 121-4.

43. Anand SS, Razak F, Davis AD, Jacobs R, Vuksan V, Teo K, et al. Social disadvantage and cardiovascular disease: development of an index and analysis of age, sex, and ethnicity effects. Int J Epidemiol 2006; 35:1239-45.

44. Brave Heart MY. Gender differences in the historical trauma response among the Lakota. J Health Soc Policy 1999; 10:1-21.
45. Coimbra Jr. CEA, Santos RV. Saúde, minorias e desigualdade: algumas teias de inter-relações, com ênfase nos povos indígenas no Brasil. Ciênc Saúde Coletiva 2000; 5:125-32.

46. Barker DJP. Fetal and infant origins of adult disease. London: BMJ Publishing Group; 1992.

47. World Health Organization. Programming of chronic disease by impaired fetal nutrition: evidence and implications for policy and intervention strategies. Geneva: World Health Organization; 2002.

48. Reid JL, Morton DJ, Wingard DL, Garret MD, von Muhlen D, Slymen D, et al. Sex and age differences in the association of obesity and smoking with hypertension and type 2 diabetes in Southern California American Indians, 2002-2006. Ethn Dis 2010; 20:231-8.

49. Minor D, Wofford M, Wyatt SB. Does socioeconomic status affect blood pressure goal achievement? Curr Hypertens Rep 2008; 10:390-7.

Submitted on 10/Apr/2014

Final version resubmitted on 12/Jul/2014

Approved on 28/Jul/2014 